\title{
THE EFFECT OF EXTRACORPOREAL SHOCK WAVE THERAPY ON INFLAMMATION PROCESS OF CALCANEAL SPUR
}

\author{
Desy Kurniawati Tandiyo'), Ratna Darjanti Haryadi²), \\ Ari Probandari3), Didik Gunawan Tamtomo4) \\ 1)Doctoral Program of Medicine, Universitas Sebelas Maret \\ ${ }^{2}$ )Department of Physical Medicine and Rehabilitation, Faculty of Medicine, \\ Universitas Airlangga, Dr.Soetomo Hospital, Surabaya \\ 3)Department of Public Health, Faculty of Medicine, Universitas Sebelas Maret, \\ 4)Department of Anatomy, Faculty of Medicine, Universitas Sebelas Maret
}

\begin{abstract}
Background: Plantar heel pain is the most common complaint and occurs in 11$15 \%$ of adults. Studies have shown most plantar heel pain is associated with calcaneal spur. This study aimed to examine the effect of extracorporeal shock wave therapy (ESWT) on inflammation process of calcaneal spur.

Subjects and Method: This was arandomized controlled trial conducted atthe Medical Rehabilitation Installation, Dr. Moewardi Hospital, Surakarta, Central Java. A sample of 60 calcaneal spur patients was randomized into two groups: (1) 30 patients in the experimental group receiving ultrasound diathermy (USD) and ESWT, (2) 30 patients in the control group receiving USD. The dependent variables were pain and TNF- $\alpha$ plasma level. The independent variables were ESWT and USD. ESWT was given on the pain point with 2000 shock frequency, 2 barr intensity, and 6 times with 7-10 days interval. USD was given on the pain point, continuous, $0.1 \mathrm{~W} / \mathrm{cm}^{2}, 10$ minutes, 6 times at 3-5 days interval. Pain level was measured by visual analogue scale (VAS). TNF- $\alpha$ plasma level was measured by cytometry. The data were analyzed by Mann-Whitney test.

Results: There was no significant difference in VAS pain score after treatment in the resting period between the experimental group (median=3) and control group (median $=3$ ) with $\mathrm{p}=0.105$. There was no significant difference in VAS pain score after treatment when waking up between the experimental group (median $=5$ ) and control group (median $=5$ ) with $\mathrm{p}=0.389$. There was no significant difference in VAS pain score after activity between the experimental group (median $=4$ ) and control group (median $=4$ ) with $\mathrm{p}=0.676$. TNF $-\alpha$ plasma level was higher in the experimental group (mean $=1815.17 ; \mathrm{SD}=2975.69$ ) than the control group (mean $=245.76 ; \mathrm{SD}=52.67)$ with $\mathrm{p}=0.001$.
\end{abstract}

Conclusion: ESWT increases TNF- $\alpha$ plasma level after therapy indicating an inflammation process.

Keywords: ESWT, calcaneal spur, pain, TNF- $\alpha$

\section{Correspondence:}

Desy Kurniawati Tandiyo. Doctoral Program of Medicine, Universitas Sebelas Maret, Jl. Ir. Sutami No. 36 A, Surakarta 57126, Central Java.

Email: tandiyo.desy@yahoo.co.id. Mobile: 08165452220.

Mid-International Conference on Public Health, Best Western Premier Hotel, Solo, Indonesia, 18-19 April $2018 \mid 252$ https://doi.org/10.26911/mid.icph.2018.05.14 